Fishing Resources / Aquaculture Received on: 06/06/2021 Accepted on: 01/10/2021

\title{
Performance of bullfrog tadpoles (Lithobates catesbeianus) fed balanced diets using alternative energy ingredients containing vegetable mesocarp
}

Desempenho de girinos de rã-touro (Lithobates catesbeianus) alimentados com dietas balanceadas com ingredientes de energia alternativa utilizando mesocarpo vegetal

${ }^{1,3}$ Seixas Filho, José Teixeira

https://orcid.org/0000-0002-5021-1290

${ }^{3}$ Pinto, Elaine da Conceição

https://orcid.org/0000-0002-3863-6990

${ }^{1}$ Mello, Diego dos Santos

https://orcid.org/0000-0002-9192-9792

${ }^{3}$ Silva, William Nascimento

${ }^{2,3}$ Mello, Silvia Conceição Reis Pereira

https://orcid.org/0000-0002-5537-3563

${ }^{4}$ Pereira, Marcelo Maia

https://orcid.org/0000-0002-1898-2722

${ }^{3}$ Dias, Giselle Eler Amorim

https://orcid.org/0000-0002-4066-3824

${ }^{1}$ Centro Universitário Augusto Motta - UNISUAM, Av. Paris, 84 - CEP: 21041-020, Bonsucesso, Rio de Janeiro/RJ, Brasil

${ }^{2}$ Empresa de Pesquisa Agropecuária do Estado do Rio de Janeiro - PESAGRO, Rua Alameda

São Boaventura nº 770, CEP: 20071-004 - Fonseca - Niterói/ RJ, Brasil

${ }^{3}$ Fundação Instituto de Pesca do estado do Rio de Janeiro, Estação Experimental de Aquicultura, Av. Dom João VI, 1746 - Guaratiba, Rio de Janeiro/RJ, Brazil

${ }^{4}$ Fundação Instituto de Pesca do Estado do Rio de Janeiro, Centro de Treinamento em Aquicultura, Rio das Flores, RJ, Brazil

*Mail for correspondence: mmaiap2001@yahoo.com.br 


\begin{abstract}
The objective of this study was to evaluate the performance and metamorphosis of bullfrog tadpoles (Lithobates catesbeianus) fed balanced diets, wherein corn flour was replaced with banana, avocado, and pumpkin meal (all made without the epicarp). Using a completely randomized design, the animals were stored in tanks with a capacity of $30 \mathrm{~L}$ in a water recirculation system at a density of 1 tadpole/L. Through biweekly biometric measurements, the weight, standard, and total length were evaluated to determine metamorphic development, weight gain, consumption, feed conversion, specific growth rate, survival, physical-chemical parameters of water, and the percentage carcass composition (only at the end). Tadpoles fed rations balanced with pumpkin and banana flour performed the best, followed by those fed avocado meal and those fed the control ration ( $\mathrm{p}<0.05)$. It can be concluded that growth performance is improved in animals fed diets containing 10\% pumpkin and banana meal instead of corn, and tadpoles that received the avocado meal had the same performance as the conventional diets. Research should be carried out to assess other avenues for the replacement of ingredients in rations for bullfrog tadpoles.
\end{abstract}

Keywords: carbohydrate, formulation, lipid, protein

\title{
RESUMO
}

O objetivo deste trabalho foi avaliar o desempenho e a metamorfose de girinos de rãtouro (Lithobates catesbeianus) alimentados com dietas balanceadas com farinha de banana, abacate e abóbora, todas feitas sem epicarpo, em substituição à farinha de milho. Utilizando um delineamento inteiramente casualizado, os animais foram colocados em tanques com capacidade de 30 litros em sistema de recirculação de água com densidade de 1 girino / L. Por meio de biometria quinzenal foram avaliados peso, comprimento padrão e total, quanto ao desenvolvimento metamórfico, ganho em peso, consumo, conversão alimentar, taxa de crescimento específico, sobrevivência, parâmetros físico-químicos da água e composição centesimal da carcaça (somente no final). Os resultados mostraram melhor desempenho para girinos alimentados com ração balanceada com farinha de abóbora e banana, seguidos daqueles alimentados com farelo de abacate e alimentados com ração controle $(\mathrm{p}<0,05)$. Os animais alimentados com as duas últimas rações não diferiram ( $p>0,05$ ). Pode-se concluir que houve melhor desempenho nos animais alimentados com dietas contendo $10 \%$ de abóbora e farelo de banana ao invés de milho, e aqueles que receberam farelo de abacate com o mesmo desempenho das dietas tradicionais. Pesquisas devem ser realizadas para avaliar outros níveis de reposição desses nutrientes por girinos de rã-touro.

Palavras-chave: carboidrato, formulação, lipídio, proteína

\section{INTRODUCTION}

Many of the ingredients that make up the rations used in aquaculture in Brazil are still not studied in relation to the intense peculiarities of the digestive physiology of aquatic organisms bred in captivity, especially in frog farming (Seixas Filho et al., 2011). 
Although a satisfactory number of feedstuffs are available in Brazil for dietary formulations, only few of these ingredients have been evaluated for their digestibility in bullfrog tadpoles (Albinati et al., 2000; Secco et al., 2005; Oliveira et al., 2008). Digestibility values are available for only 10 feed ingredients used for bullfrog tadpoles, whereas there are values for 40 feedstuffs used in tilapia diets, according to the Brazilian Nutrition Tables (Furuya, 2010).

The digestive tract in the tadpole phase, unlike fingerlings, is in provisional formation and includes the pancreas and liver from the beginning of exogenous feeding (Seixas Filho et al., 2008a) when the animal is in the 25th larval stage, according to Gosner (1960). The tract is however only functional approximately 30 days later (Seixas Filho et al., 2011). This makes it difficult to absorb some of the nutrients present in the feed ingredients. This is aggravated when nutrients come from plant seeds with a high concentration of hemicellulose and lignin in the cell wall, such as corn and soybean. In contrast, cells from the ovarian region of the plants have lower fiber in the cell walls to facilitate expansion during fruit formation and are postulated to be utilized better. Among the feed ingredients that could be used as alternatives for bullfrog tadpoles, three are potentially interesting due to the structure of their cell wall, namely the meals of banana (Musa ssp.), pumpkin (Cucurbita maxima), and avocado (Persea americana) (Wegner and Belik, 2012; Silva et al., 2015).

In contrast to corn, which is the seed of the vegetable, banana, squash, and avocado are formed from a structure of the plant tissue called the "pseudofruit" in the case of the banana, and the "mesocarp" in the case of pumpkin and avocado; all have thinner cell walls than corn grain. The differences in the cellular structures permit the hypothesis that there is a better digestibility of these ingredients in the ration for bullfrog tadpoles.

The objective of the present work was to evaluate the performance of bullfrog tadpoles fed balanced rations using flours made from the mesocarp of banana, avocado, and pumpkins to replace $77 \%$ of the total amount of corn.

\section{MATERIAL AND METHODS}

\section{Experimental conditions and animals}

The experiment, which lasted 60 days, was conducted in the city of Rio de Janeiro, State of Rio de Janeiro, of Brazil (22 $59^{\prime}$ latitude and $43^{\circ} 35^{\prime} 22.4^{\prime \prime}$ longitude). Research on animals was conducted according to the Institutional Committee on Animal Use (number of protocol: 002/2018).

A total of 480 bullfrog tadpoles in Gosner stage 25 (1960), with a mean weight of $0.107 \pm 0.004 \mathrm{~g}$, originating from the same spawn, were used. The animals were housed in $60 \%$ of the volume of $50 \mathrm{~L}$ polypropylene tanks at a density of 1 tadpole/L, which corresponded to one experimental unit. The polypropylene tanks were placed side by side on benches in 16 units aerated with a $3 / 16^{\prime \prime}$ tube containing a porous stone at the terminus. The water exchange was 57 times the volume of $30 \mathrm{~L}$ in $24 \mathrm{~h}$.

The experimental units were siphoned daily and the water temperature was measured with a thermometer. Water levels of $\mathrm{NH}_{4}$ and $\mathrm{NH}_{3}$ and water $\mathrm{pH}$ 
were obtained daily using a commercial kit for the control of water quality in the tanks $\left(\mathrm{LABTEST}^{\circledR}\right)$.

\section{Experimental design and diets}

The experimental design was completely randomized and consisted of four treatments, with four replications per treatment, totaling 16 experimental units. Treatments corresponded to the substitution of $10 \%$ of the corn for peeled banana, avocado, and pumpkin meals (Table 1), plus a corn-based control. The diets (Table 2) were formulated according to the digestibility values reported by Secco et al. (2005).

The animals received the diets in meal form (Seixas Filho et al., 1998), corresponding to $8 \%$ of their live weight. The diet was supplied four times daily, and the amounts provided were recorded for the calculation of feed intake.

Table 1. Composition of peeled banana, pumpkin, and avocado meals substituting $10 \%$ of the corn in diets for bullfrog tadpoles.

\begin{tabular}{lllll}
\hline Composition & Corn & $\begin{array}{l}\text { Peeled } \\
\text { banana }\end{array}$ & $\begin{array}{l}\text { Peeled } \\
\text { avocado }\end{array}$ & $\begin{array}{l}\text { Peeled } \\
\text { pumpkin }\end{array}$ \\
\hline Moisture $(\mathrm{g} / \mathrm{kg})$ & 120.5 & 186.9 & 55.5 & 109.2 \\
Protein $(\mathrm{g} / \mathrm{kg})$ & 74.0 & 34.4 & 54.9 & 130.1 \\
Fat $(\mathrm{g} / \mathrm{kg})$ & 32.8 & 4.4 & 493.5 & 47.7 \\
Ash $(\mathrm{g} / \mathrm{kg})$ & 9.1 & 25.0 & 45.1 & 56.1 \\
Fiber $(\mathrm{g} / \mathrm{kg})$ & 55.0 & 9.7 & 59.6 & 63.7 \\
Starch $(\mathrm{g} / \mathrm{kg})$ & 708.6 & 739.6 & 291.4 & 593.2 \\
\hline Gross energy $(\mathrm{kcal} / \mathrm{kg})$ & $3,954.07$ & $3,714.02$ & $7,177.04$ & $3,769.50$ \\
\hline
\end{tabular}


Table 2. Bullfrog tadpole diets containing peeled banana, pumpkin, and avocado meals as substitutes for $10 \%$ corn.

\begin{tabular}{lllll}
\hline Ingredient & Corn & Banana & Avocado & Pumpkin \\
\hline Salmon meal $(\mathrm{g} / \mathrm{kg})$ & 178.8 & 178.8 & 178.8 & 178.8 \\
Soybean meal $(\mathrm{g} / \mathrm{kg})$ & 250.0 & 250.0 & 250.0 & 250.0 \\
Corn gluten $(\mathrm{g} / \mathrm{kg})$ & 200.0 & 200.0 & 200.0 & 200.0 \\
Corn $(\mathrm{g} / \mathrm{kg})$ & 130.0 & 30.0 & 30.0 & 30.0 \\
Wheat bran $(\mathrm{g} / \mathrm{kg})$ & 105.0 & 105.0 & 105.0 & 105.0 \\
Corn starch $(\mathrm{g} / \mathrm{kg})$ & 100.0 & 100.0 & 100.0 & 100.0 \\
Peeled banana $(\mathrm{g} / \mathrm{kg})$ & - & 100.0 & - & - \\
Peeled pumpkin $(\mathrm{g} / \mathrm{kg})$ & - & - & - & 100.0 \\
Peeled avocado $(\mathrm{g} / \mathrm{kg})$ & - & - & 100.0 & - \\
Soybean oil $(\mathrm{g} / \mathrm{kg})$ & 30.0 & 30.0 & 10.0 & 30.0 \\
Inert $($ sand) $(\mathrm{g} / \mathrm{kg})$ & - & - & 20.0 & - \\
Premix & 6.0 & 6.0 & 6.0 & 6.0 \\
BHT & 0.2 & 0.2 & 0.2 & 0.2 \\
\hline Total $(\mathrm{kg})$ & $1,000.0$ & $1,000.0$ & $1,000.0$ & $1,000.0$ \\
\hline Crude protein $(\mathrm{g} / \mathrm{kg})$ & 342.6 & 338.7 & 340.7 & 348.3 \\
Digestible protein $(\mathrm{g} / \mathrm{kg})$ & 304.2 & 300.1 & 301.7 & 307.8 \\
Gross energy $(\mathrm{kcal} / \mathrm{kg})$ & $4,478.58$ & $4,454.58$ & $4,618.36$ & $4,460.12$ \\
Digestible energy $(\mathrm{kcal} / \mathrm{kg})$ & $3,561.87$ & $3,507.27$ & $3,665.08$ & $3,511.71$ \\
Ether extract $(\mathrm{g} / \mathrm{kg})$ & 61.3 & 58.5 & 87.4 & 62.8 \\
\hline
\end{tabular}

*Values calculated based on the digestibility coefficients reported by Secco et al. (2005).

${ }^{1}$ Vitamin A (IU/kg) 600,000; vitamin D3 (IU/kg) 600,000; vitamin E (mg/kg) 12,000; vitamin $\mathrm{K} 3 \quad(\mathrm{mg} / \mathrm{kg}) \quad 631$; thiamine B1 (mg/kg) 1,176; riboflavin B2 $(\mathrm{mg} / \mathrm{kg}) \quad 1,536 ;$ pyridoxine B6 $(\mathrm{mg} / \mathrm{kg}) \quad 1,274$; vitamin B12 $(\mu \mathrm{g} / \mathrm{kg})$ 4,000; $\quad$ niacin $(\mathrm{mg} / \mathrm{kg}) \quad 19,800$; pantothenic acid B3 (mg/kg) 3,920; folic acid $(\mathrm{mg} / \mathrm{kg}) 192 ;$ biotin $(\mathrm{mg} / \mathrm{kg})$ 20; vitamin C (mg/kg) 40,250; choline $(\mathrm{mg} / \mathrm{kg}) 30,000$; moisture (\%) 2.0; ash (\%) 71.64; magnesium (\%) 0.0085; sulfur (\%) 1.159; iron $(\mathrm{mg} / \mathrm{kg}) 25,714$; copper $(\mathrm{mg} / \mathrm{kg}) \quad 1,960 ;$ manganese $(\mathrm{mg} / \mathrm{kg})$ 13,345; zinc $(\mathrm{mg} / \mathrm{kg}) 30,000$; iodine $(\mathrm{mg} / \mathrm{kg})$ 939; selenium $(\mathrm{mg} / \mathrm{kg})$ 30. 


\section{Measurements}

Biometric measurements were taken at the beginning and at $15,30,45$, and 60 days of the experiment and consisted of the measurement of individual tadpole weight $(\mathrm{g})$ on a digital scale $(0.001 \mathrm{~g})$ and total and standard length using a digital caliper $(0.01 \mathrm{~mm})$. Additionally, metamorphic development was evaluated based on Gosner stages (1960) with a trinocular stereoscopic microscope equipped with $10 \times$ to $40 x$ lenses.

The following performance parameters were evaluated: body weight, standard and total lengths, and metamorphic development obtained during each measurement $(1,15,30,45$, and 60 days); and weight gain, feed intake, feed conversion, specific growth rate, and survival rate for the entire experimental period (1-60 days).

Water quality was monitored by measuring water temperature, total ammonia $\left(\mathrm{NH}_{3}+\mathrm{NH}_{4}\right)$, toxic ammonia $\left(\mathrm{NH}_{3}\right)$, and $\mathrm{pH}$ during the periods described above (Table 3).

At the end of the experiment, $30 \mathrm{~g}$ of tadpole live weight from each replication was sampled for analysis of percentage composition (water, protein, ash, and fat).

Table 3. Water quality in the rearing tanks of bullfrog tadpoles fed diets containing peeled banana, pumpkin, and avocado meals as substitutes for corn.

\begin{tabular}{lllll}
\hline Ingredient & $\begin{array}{l}\text { Water temperature } \\
\left({ }^{\circ} \mathrm{C}\right)\end{array}$ & $\begin{array}{l}\mathrm{NH}_{3}+\mathrm{NH}_{4} \\
(\mathrm{mg} / \mathrm{L})\end{array}$ & $\begin{array}{l}\mathrm{NH}_{3} \\
(\mathrm{mg} / \mathrm{L})\end{array}$ & $\mathrm{pH}$ \\
\hline Corn & $24.3 \pm 0.1$ & $0.204 \pm 0.012$ & $0.0016 \pm 0.0001$ & $7.19 \pm 0.02$ \\
Banana & $24.4 \pm 0.1$ & $0.195 \pm 0.006$ & $0.0015 \pm 0.0001$ & $7.20 \pm 0.01$ \\
Avocado & $24.4 \pm 0.1$ & $0.191 \pm 0.012$ & $0.0016 \pm 0.0001$ & $7.18 \pm 0.01$ \\
Pumpkin & $24.5 \pm 0.1$ & $0.026 \pm 0.010$ & $0.0016 \pm 0.0001$ & $7.18 \pm 0.01$ \\
$P$-value & 0.5679 & 0.7254 & 0.9126 & 0.8025 \\
\hline
\end{tabular}

\section{Sample processing and laboratory tests}

After 60 days of the experiment, tadpole samples (whole body) were ground in a meat processor and stored in labeled jars in a freezer at $-10{ }^{\circ} \mathrm{C}$. Dry matter was determined in an oven at $105{ }^{\circ} \mathrm{C}$ (Silva and Queiroz, 2006). Crude protein was analyzed using the Kjeldahl method (AOAC, 1984); crude fat using the Folch method (Folch et al. 1957); and ash by incineration in a muffle furnace at $600{ }^{\circ} \mathrm{C}$ (Silva and Queiroz, 2006).

\section{Statistical analysis}

Performance and percentage composition data were analyzed using the Shapiro-Wilk and Bartlett tests to check normality and homoscedasticity of the data. Results were subjected to analysis of variance, and the mean values were compared using the Duncan test at the 5\% level of significance, except for metamorphic development, in which the stages of metamorphosis underwent linear regression as a function of age or time of the experiment (days). All statistical procedures were performed using SAS 9.2. software (SAS, 2008).

\section{RESULTS}

Differences in body weight between diets were observed at day 30 of the 
experiment $(\mathrm{p}<0.05)$, particularly in animals fed banana meal diet (1.85 \pm $0.06 \mathrm{~g})$. After 45 days, tadpoles fed pumpkin meal diet had a similar body weight $(1.93 \pm 0.04 \mathrm{~g})$ to that of animals fed banana meal diet, a pattern that continued until the end of the experiment. The body weight of tadpoles receiving the control diet (1.63 $\pm 0.08 \mathrm{~g}$ ), which had a higher corn content, was similar to that of animals fed avocado meal diet $(1.49 \pm 0.04 \mathrm{~g})$ throughout the experimental period (Table 4).

Table 4. Weight, total length, and standard length of bullfrog tadpoles fed diets containing peeled banana, pumpkin, and avocado meals as substitutes for corn.

\begin{tabular}{llllll}
\hline Diet & 1 day & 15 days & 30 days & 45 days & 60 days \\
\hline & Body weight $(\mathrm{g})$ & & & & \\
Corn & $0.12 \pm 0.01$ & $0.33 \pm 0.01$ & $0.57 \pm 0.02 \mathrm{~b}$ & $1.02 \pm 0.07 \mathrm{~b}$ & $1.63 \pm 0.08 \mathrm{~b}$ \\
Banana & $0.10 \pm 0.01$ & $0.32 \pm 0.04$ & $0.69 \pm 0.02 \mathrm{a}$ & $1.25 \pm 0.03 \mathrm{a}$ & $1.85 \pm 0.06 \mathrm{a}$ \\
Avocado & $0.10 \pm 0.01$ & $0.28 \pm 0.01$ & $0.57 \pm 0.01 \mathrm{~b}$ & $0.95 \pm 0.04 \mathrm{~b}$ & $1.49 \pm 0.04 \mathrm{~b}$ \\
Pumpkin & $0.10 \pm 0.01$ & $0.33 \pm 0.03$ & $0.62 \pm 0.04 \mathrm{~b}$ & $1.29 \pm 0.07 \mathrm{a}$ & $1.93 \pm 0.04 \mathrm{a}$ \\
p value & 0.2054 & 0.3788 & 0.0117 & 0.0016 & 0.0004 \\
& Total length (mm) & & & & \\
Corn & $19.03 \pm 0.50$ & $34.04 \pm 0.72$ & $40.65 \pm 1.67$ & $50.31 \pm 1.01$ & $59.17 \pm 2.43 \mathrm{~b}$ \\
Banana & $19.57 \pm 0.24$ & $31.03 \pm 2.63$ & $43.12 \pm 1.83$ & $53.07 \pm 0.69$ & $61.41 \pm 2.13 \mathrm{~b}$ \\
Avocado & $19.61 \pm 1.68$ & $32.55 \pm 1.96$ & $41.44 \pm 0.76$ & $49.61 \pm 1.28$ & $56.84 \pm 1.64 \mathrm{~b}$ \\
Pumpkin & $21.05 \pm 1.04$ & $32.99 \pm 1.59$ & $44.19 \pm 0.87$ & $54.39 \pm 1.89$ & $66.88 \pm 1.14 \mathrm{a}$ \\
p value & 0.3942 & 0.7202 & 0.2968 & 0.0699 & 0.0164 \\
& Standard length (mm) & & & \\
Corn & $8.72 \pm 0.27$ & $13.81 \pm 0.39$ & $16.76 \pm 0.53$ & $20.57 \pm 0.23$ & $23.89 \pm 0.82 \mathrm{~b}$ \\
Banana & $8.64 \pm 0.32$ & $13.19 \pm 0.84$ & $17.70 \pm 0.84$ & $21.29 \pm 0.50$ & $25.22 \pm 0.25 \mathrm{a}$ \\
Avocado & $8.62 \pm 0.28$ & $13.35 \pm 0.73$ & $16.78 \pm 0.24$ & $19.68 \pm 0.50$ & $22.23 \pm 0.35 \mathrm{~b}$ \\
Pumpkin & $9.43 \pm 0.47$ & $13.01 \pm 0.46$ & $17.55 \pm 0.31$ & $21.76 \pm 0.89$ & $26.54 \pm 0.29 \mathrm{a}$ \\
p value & 0.3257 & 0.8261 & 0.4793 & 0.1122 & 0.0003 \\
\hline
\end{tabular}

${ }^{1}$ Mean values in the same column followed by different lowercase letters differ using Duncan's test $(\mathrm{p}<0.05)$.

A significant difference in the total length of bullfrog tadpoles (Table 4) was only observed at the end of the experiment, when tadpoles fed pumpkin meal diet $(66.88 \pm 1.64 \mathrm{~mm})$ displayed a better result $(\mathrm{p}<0.05)$ than the control $(59.19 \pm 2.43 \mathrm{~mm})$ and animals receiving the banana $(61.41 \pm 2.13 \mathrm{~mm})$ and avocado meal diets $(56.84 \pm 1.64$ $\mathrm{mm})$. Differences in mean standard length were also observed only at the end of the experiment. However, the standard length was similar in tadpoles fed banana $(25.22 \pm 0.25 \mathrm{~mm})$ and pumpkin meal diets $(26.54 \pm 0.29 \mathrm{~mm})$; both groups showed higher values than those fed the control $(23.89 \pm 0.82 \mathrm{~mm})$ and avocado meal diets $(22.23 \pm 0.25$ mm) (Table 4).

Weight gain, feed intake, feed conversion, and specific growth rate at 60 days were higher $(\mathrm{p}<0.05)$ in tadpoles fed pumpkin and banana meal diets than those in the control and tadpoles fed avocado meal diets. Feed conversion was similar ( $p>0.05$ ) for all treatments, since tadpoles that gained more weight consumed more feed and 
those that consumed less feed grew less. An excellent survival rate above $90 \%$ was observed for all diets, with no significant differences $(\mathrm{p}>0.05)$ between treatments (Table 5).

Table 5. Weight gain, feed intake, feed conversion, specific growth rate, and survival of bullfrog tadpoles fed diets containing peeled banana, pumpkin, and avocado meal as substitutes for corn.

\begin{tabular}{llllll}
\hline Ingredient & $\begin{array}{l}\text { Weight gain } \\
(\mathrm{g})\end{array}$ & $\begin{array}{l}\text { Feed intake } \\
(\mathrm{g})\end{array}$ & $\begin{array}{l}\text { Feed } \\
\text { conversion } \\
(\mathrm{g} / \mathrm{g})\end{array}$ & $\begin{array}{l}\text { Specific } \\
\text { growth rate } \\
(\% / \mathrm{day})\end{array}$ & $\begin{array}{l}\text { Survival rate } \\
(\%)\end{array}$ \\
\hline Corn & $1.51 \pm 0.08 \mathrm{~b}$ & $2.15 \pm 0.07 \mathrm{~b}$ & $1.44 \pm 0.04$ & $4.64 \pm 0.13 \mathrm{~b}$ & $91.7 \pm 0.96$ \\
Banana & $1.75 \pm 0.06 \mathrm{a}$ & $2.44 \pm 0.08 \mathrm{a}$ & $1.40 \pm 0.08$ & $5.20 \pm 0.16 \mathrm{a}$ & $93.3 \pm 2.36$ \\
Avocado & $1.39 \pm 0.03 \mathrm{~b}$ & $1.99 \pm 0.06 \mathrm{~b}$ & $1.43 \pm 0.05$ & $4.79 \pm 0.11 \mathrm{~b}$ & $95.0 \pm 0.96$ \\
Pumpkin & $1.83 \pm 0.04 \mathrm{a}$ & $2.43 \pm 0.13 \mathrm{a}$ & $1.33 \pm 0.10$ & $5.22 \pm 0.15 \mathrm{a}$ & $94.0 \pm 2.10$ \\
p value & 0.0004 & 0.0112 & 0.7213 & 0.0222 & 0.2230 \\
\hline
\end{tabular}

${ }^{1}$ Mean values in the same column followed by different lowercase letters were different using Duncan's test $(\mathrm{p}<0.05)$.

The body composition of bullfrog tadpoles differed between treatments $(\mathrm{p}$ $<0.05)$. Tadpoles fed avocado meal diet showed a higher moisture content than the other treatments and control. Protein deposition was lower in tadpoles fed pumpkin meal diet than that in the other groups. Tadpoles fed avocado meal diet showed an ether extract content similar to that observed in animals fed pumpkin meal diet $(p>0.05)$ and lower than that found in animals fed only the corn and banana meal diets $(\mathrm{p}<0.05)$. Taken together, the body composition results reveal that these alternative feeds induce a different metabolic behavior in bullfrog tadpoles (Table 6).

Table 6. Moisture, protein, ether extract, and ash content of bullfrog tadpoles fed diets containing peeled banana, pumpkin, and avocado meals as substitutes for corn.

\begin{tabular}{lllll}
\hline Diet & Moisture $(\%)$ & Protein $(\%)$ & Ether extract $(\%)$ & Ash $(\%)$ \\
\hline Corn & $87.29 \pm 0.26 \mathrm{~b}$ & $7.35 \pm 0.45$ & $3.37 \pm 0.13 \mathrm{a}$ & $1.42 \pm 0.03$ \\
Banana & $87.55 \pm 0.35 \mathrm{~b}$ & $6.53 \pm 0.32$ & $3.24 \pm 0.13 \mathrm{a}$ & $1.36 \pm 0.05$ \\
Avocado & $88.83 \pm 0.33 \mathrm{a}$ & $6.59 \pm 0.22$ & $2.69 \pm 0.12 \mathrm{c}$ & $1.39 \pm 0.06$ \\
Pumpkin & $87.87 \pm 0.23 \mathrm{~b}$ & $6.14 \pm 0.67$ & $2.99 \pm 0.10 \mathrm{~b}$ & $1.37 \pm 0.03$ \\
\hline p value & 0.0035 & 0.0601 & 0.0116 & 0.8143 \\
\hline 'Mean values in the same column followed by different lowercase letters differ using Duncan's \\
test $(\mathrm{p}<0.05)$.
\end{tabular}

Linear regression analysis of tadpole metamorphic stages revealed normal development for all treatments and controls (Figure 1). Comparative evaluation between treatments was not performed; however, the tadpoles that received the novel feeds were in more advanced stages than the control, especially those fed banana and pumpkin flour diets. 

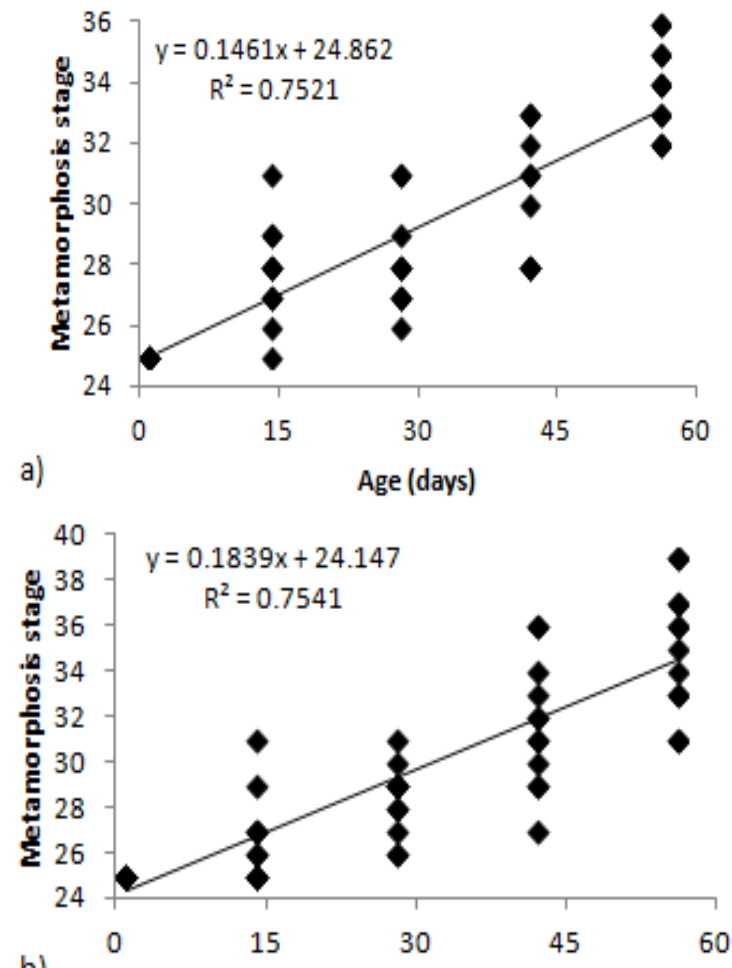

b)

Age (days)
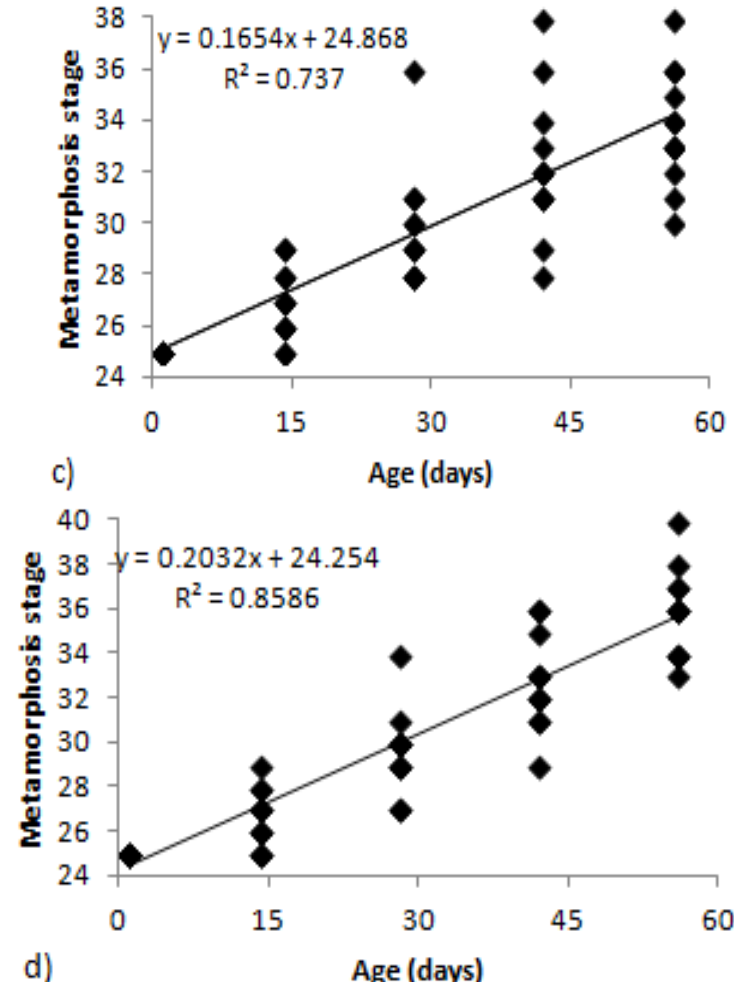

Figure 1. Developmental stages (Gosner, 1960) of bullfrog tadpoles fed diets containing (a) corn, (b) peeled banana meal, (c) avocado meal, and (d) and pumpkin meal as substitutes for corn. 


\section{DISCUSSION}

Analysis of body weight; total and standard lengths; weight gain; feed intake; specific growth rate; survival rate; moisture, protein, ether extract, and ash contents; water quality; and metamorphosis stages of bullfrog tadpoles showed better results for animals receiving peeled banana and pumpkin meals as substitutes for corn. The superiority of some diets can be explained by the nutrient composition of the corn substitutes (Table 1).

The inferior performance of animals on avocado meal compared with the other meals might be related to its high lipid content $(493.5 \mathrm{~g} / \mathrm{kg})$. Tadpoles are animals that undergo constant anatomical and physiological changes. At this stage of life, the digestive system is still not prepared with sufficient lipolytic enzymes to break down this high content of lipids and allow their absorption (Seixas Filho et al., 2008c, 2010). However, avocado meal displayed a similar result to that of corn and therefore met the objective of this study, i.e., to identify substitutes for ground corn in diets for bullfrog tadpoles.

Furthermore, studies of enzymatic activities in bullfrog tadpoles receiving commercial diets with 28\%, 32\%, 36\%, and $40 \%$ crude protein have demonstrated a higher specific activity of amylase at 18,26, 35, and 55 days of the experiment than that with lipase, which showed higher activity than trypsin (Seixas Filho et al., 2011). This knowledge confirms the potential of feed ingredients like peeled banana and peeled pumpkin for tadpole feeding as they contain a high amount of starch.
Peeled banana meal has a high starch content $(739.6 \mathrm{~g} / \mathrm{kg})$ and low crude protein $(34.4 \mathrm{~g} / \mathrm{kg})$ and fiber $(9.7 \mathrm{~g} / \mathrm{kg})$ contents. Peeled pumpkin meal also has high starch $(593.2 \mathrm{~g} / \mathrm{kg})$, medium crude protein $(130.0 \mathrm{~g} / \mathrm{kg})$, and high fiber $(63.7 \mathrm{~g} / \mathrm{kg})$ content. Corn, the replaced ingredient, is characterized by high levels of starch $(708.6 \mathrm{~g} / \mathrm{kg})$, low crude protein $(74.0 \mathrm{~g} / \mathrm{kg})$, and high fiber $(63.7$ $\mathrm{g} / \mathrm{kg}$ ). The three novel feed ingredients are high in starch, but peeled banana meal has a low fiber content, and peeled pumpkin meal, despite its high fiber content, has a medium crude protein content, which may compensate for the high levels of fiber. This information may explain the better performance of omnivorous bullfrog tadpoles fed these meals. An investigation of different plant sources (broken rice, ground corn, wheat bran, citrus pulp, and soybean hulls) containing different levels of dietary fiber in the omnivorous fish species, tilapia and catfish, showed a reduction in protein, energy, and dry matter digestibility with increasing fiber content in both species (Rodrigues et al., 2012).

Another difference between the peeled banana, avocado, and pumpkin meals and corn is their macro- and micronutrient levels. The total ash content of corn is $9.1 \mathrm{~g} / \mathrm{kg}$, while this value is $25.0 \mathrm{~g} / \mathrm{kg}$ for banana meal, 45.1 $\mathrm{g} / \mathrm{kg}$ for avocado meal, and $56.1 \mathrm{~g} / \mathrm{kg}$ for pumpkin meal, with the potassium content of pumpkin meal corresponding to $75 \%$ of total ash. However, it should be noted that the corn used in this study was an excellent source of magnesium and calcium. The future adoption of these meals by the feed industry would be an interesting strategy to offset the 
mineral deficiency of some feed ingredients.

The water $(87.29 \%$ to $88.83 \%)$, protein $(6.14 \%$ to $7.35 \%)$, fat $(2.69 \%$ to $3.37 \%)$, and ash (1.36\% to $1.42 \%)$ content of tadpoles fed corn and peeled banana, avocado, and pumpkin meal correspond to studies that determined the protein requirement for bullfrog tadpoles (Pinto et al., 2015). Additionally, they correspond to studies that compared the nutrient content between a commercial and an experimental diet for bullfrog tadpoles (Mansano et al., 2014), and research evaluating the nutrient deposition using a commercial fish diet containing $40 \%$ crude protein (Mansano et al., 2013).

Histological studies of the organs of bullfrog tadpoles have shown that diets formulated for fish can cause organ damage in the tadpoles, even those containing low protein (Seixas Filho et al., 2008a). Proteins of low biological value compromise animal health and performance (Seixas Filho et al., 2008b). The performance of the tadpoles fed peeled avocado, pumpkin, and banana meal as substitutes for corn may indicate improvement in the quality of the diets, but histological studies are necessary.

A decline in water temperature was observed throughout the experiment for all treatments, especially in the last fortnight $\left(22.7{ }^{\circ} \mathrm{C}\right)$. This had an effect on performance, particularly on specific growth rate (Table 4), since the ideal water temperature for raising bullfrog tadpoles is $25{ }^{\circ} \mathrm{C}$ (Hoffmann et al., 1989). However, the overall mean temperature $\left(24.4^{\circ} \mathrm{C}\right)$ was close to the thermal comfort zone (Table 6). The remaining parameters related to water quality, such as toxic ammonia $\left(\mathrm{NH}_{3}\right)$ levels, total ammonia $\left(\mathrm{NH}_{3}+\mathrm{NH}_{4}\right)$, and $\mathrm{pH}$, displayed acceptable values (Table 6) for the maintenance of homeostasis in bullfrog tadpoles (Seixas Filho et al., 2012; Borges et al., 2014).

\section{CONCLUSION}

The performance of bullfrog tadpoles fed peeled banana, avocado, and pumpkin meals made viable the inclusion of these meals as substitutes for corn in tadpole diets.

\section{REFERENCES}

Albinati, R. C. B.; Lima, S. L.; Tafuri, M. L.; Donzele, J. L. Digestibilidade aparente de dois alimentos protéicos e três energéticos para girinos de rã-touro (Rana catesbeiana, Shaw, 1802). Revista brasileira de zootecnia 29 , 2151-2156. 2000.

AOAC - Association of Official Analytical Chemists Official methods of analysis. 14th ed. Arlington, Virginia, 1141p, 1984.

Borges, F. F.; De Stéfani, M. V.; Amaral, L. A. Quality of the effluents of bullfrog tadpole ponds. Boletim do instituto de pesca 40, 409-471. 2014. https://www.pesca.sp.gov.br/boletim/in dex.php/bip/article/view/1050/1028

Folch, J.; Lees, M. S.; Tanley-Sloane, G. H. A simple method for the isolation purification of total lipids from animal tissues. Journal Biology Chemistry 226, 497-509. 1957. https://www.ncbi.nlm.nih.gov/pubmed/ 13428781 
Furuya, W. M. Tabelas brasileiras para a nutrição de tilápias, 100p. GFM: Toledo, 2010.

Gosner, K. L. A simplified table for staging anuran embryos and larvae with notes on identification. Herpetologica 16, 183-190. 1960. https://www.scienceopen.com/documen t?vid=5a9edee $9-d c 4 b-4393-a 837$ adeec5645506

Hoffmann, D. F.; Leboute, E. M.; Souza, S. M. G. Efeito da temperatura e desenvolvimento de girinos de rã-touro (Rana catesbeiana Shaw, 1802). Revista Sociedade Brasileira Zootecnia 18, 557-566. 1989.

Mansano, C. F. M.; De Stéfani, M. V.; Pereira, M. M.; Macente, B. I. Deposição de nutrientes na carcaça de girinos de rã-touro. Pesquisa Agropecuária Brasileira 48, 885-891. 2013. https://doi.org/10.1590/S0100$204 X 2013000800011$.

Mansano, C. M.; De Stéfani, M. V.; Pereira, M. M.; Nascimento, T. R.; Macente, B. I. Morphometric growth characteristics and body composition of bullfrog tadpoles in captivity. Semina: Ciências Agrárias 35, 1425-1438. 2014.

http://www.uel.br/revistas/uel/index.php /semagrarias/article/view/16638

Oliveira, M. Md; Pimenta, M. EdS. G.; Camargo, A. CdS.; Pimenta, C. J.; Logato, P. V. R. Silagem ácida de resíduos da filetagem de tilápias para girinos de rã-touro (Rana catesbeiana Shaw, 1802): digestibilidade e desempenho. Ciência e Agrotecnologia 32, 618-625. 2008.
https://doi.org/10.1590/S1413-

70542008000200042 .

Pinto, D. F. H.; Mansano, C. F. M.; De Stéfani, M. V.; Pereira, M. M. Optimal digestible protein level for bullfrog tadpoles. Aquaculture 440, 12-16. 2015.

https://doi.org/10.1016/j.aquaculture.20 15.01.025.

Regazzi, A. J. Teste para verificar a identidade de modelos de regressão e igualdade de parâmetro no caso de dados de delineamentos experimentais. Revista Ceres 46, 383-409. 1999.

Rodrigues, A. P. O.; Gominho-Rosa, M. D. C.; Cargnin-Ferreira, E.; Francisco, A.; Fracalossi, D. M. Different utilization of plant sources by omnivores jundiá catfish (Rhamdia quelen) and nile tilápia (Orechromis niloticus). Aquaculture Nutrition 18, 65-72. 2012. https://onlinelibrary.wiley.com/doi/abs/ 10.1111/j.1365-2095.2011.00877.x

Sakomura, N. K.; Rostagno, H. S. Métodos de pesquisa em nutrição de monogástricos. Jaboticabal: Funep, 283p, 2007.

SAS Institute SAS/STAT 9.2. Users guide. SAS Institute Inc.: Cary, NC, 2008.

Secco, E. M.; Stéfani, M. V. D.; Vidotti, R. M. Apparent digestibility of different ingredients in diets for bullfrog Rana catesbeiana tadpoles. Journal of the World Aquaculture Society 36, 135140. 2005. http://dx.doi.org/10.1111/j.1749-

7345.2005.tb00140.x 
Seixas Filho, J. T.; Hipolito, M.; Carvalho, V. F. Martins. AMC RPF: Silva, L. N. S.; CASTAGNA, A. A. Alterações histopatológicas em girinos de rã-touro alimentados com rações comerciais de diferentes níveis proteicos. Revista Brasileira de Zootecnia 37, 2085-2089. 2008b. https://doi.org/10.1590/S151635982008001200002

Seixas Filho, J. T.; Mello, S. C. R. P.; Veiga, R. C. A.; Miranda, R. G. B.; Santos, C. A. N. Efeito da granulometria da ração sobre $\mathrm{O}$ desempenho de girinos de Rana catesbeiana. Revista brasileira de zootecnia 27, 224-230. 1998.

Seixas Filho, J. Td; Gomes, L. H.; Aguiar, D. V. C.; Hipolito, M.; Martins, A. M. C. R. PdF.; Chaves, A. C. P. Avaliação histológica do intestino médio, do fígado e do pâncreas de girinos de rã-touro alimentados com rações comerciais formuladas com três níveis de proteína bruta. Revista brasileira de zootecnia 37, 2090-2096. 2008a. https://doi.org/10.1590/S151635982008001200003. AMC RPF: Chaves.

Seixas Filho, J. Td; Navarro, R. D.; Pereira, M. M.; Mello, S. C. R. P.; Lanna, E. A. T.; Lima, J. L. P. Desempenho zootécnico de girinos de rã-touro com diferentes níveis de proteína e energia digestíveis. Revista Brasileira de Saúde e Produção Animal 13, 1112-1120. 2012. https://doi.org/10.1590/S151999402012000400023

Seixas Filho, J. Td; Oliveira, M. G. A.; Moura, GdS.; Garcia, S. L. R.; Lanna,
E. T. A.; Silva, L. Nd Desempenho e atividades enzimáticas em girinos de rãtouro. Pesquisa Agropecuária Brasileira 43, 1617-1624. 2008c. https://doi.org/10.1590/S0100-

204X2008001100022

Seixas Filho, J. Td; Oliveira, M. G. A.; Moura, GdS.; Lanna, E. A. T.; Garcia, S. L. R.; Lima, J. L. P. Influence of supplying bullfrog tadpoles with feed containing $28 \%$ crude protein on performance and enzymatic activities. Revista brasileira de zootecnia 39, 917. 2010. https://doi.org/10.1590/S151635982010000100002

Seixas Filho, J. Td; Oliveira, M. G. A.; Navarro, R. D.; Garcia, S. L. R.; Moura, GdS.; Ribeiro Filho, O. P. Atividades enzimáticas de girinos de rã-touro submetidos a rações com níveis de proteína. Archivos de zootecnia 60, 1161-1170. 2011. https://doi.org/10.4321/S000405922011000400031

Silva, AdA.; Barbosa Junior, J. L.; Barbosa, M. I. M. J. Farinha de banana verde como ingrediente funcional em produtos alimentícios. Ciência Rural 45, 2252-2258. 2015. https://doi.org/10.1590/01038478 cr20140332

Silva, D. J.; Queiroz, A. C. Análise de alimentos: métodos químicos e biológicos. UFV: Viçosa, MG, 235p, 2006

Trujillo, J. H. A. Alternative feedstuffs for swine in Colombia: what are our options? Revista Colombiana Ciência Pecuaria 22, 278-286. 2009. http://www.scielo.org.co/scielo.php?scri 
pt=sci_arttext\&pid=S012006902009000 300004

Wegner, R. C.; Belik, Y.; W. Distribuição de hortifruti no Brasil: papel das Centrais de Abastecimento e dos supermercados. Cuadernos de Desarrollo Rural 9, 195-220. 2012. http://www.scielo.org.co/pdf/cudr/v9n6 9/v9n69a10.pdf 